\title{
PENDISTRIBUSIAN ZAKAT BERBASIS EKONOMI PADA DOMPET DHUAFA PROVINSI RIAU
}

\author{
Hamidah dan Syahril Romli \\ Fakultas Dakwah dan Komunikasi UIN Suska Riau \\ Email: hamidahya965@gmail.com
}

\begin{abstract}
Abstrak
Penelitian ini dilatarbelakangi oleh persoalan kesenjangan sosial yang terjadi di Provinsi Riau yaitu untuk memutuskan rantai kemiskinan di masyarakat yang berdampak pada ekonomi mustahik khususnya. Untuk itu, Lembaga Amil Zakat Dompet Dhuafa Riau sebagai penghimpun dana zakat, dituntut untuk professional dan inovatif dalam mendistribusikan dana zakat secara produktif seperti adanya program dibidang ekonomi yang berbentuk pemberdayaan, hal ini diharapkan dapat mempercepat upaya pengentasan kemiskinan di masyarakat. Mereka yang awalnya mustahik pada akhirnya berubah menjadi muzaki. Penelitian ini dilakukan di Dompet Dhuafa Riau. Permasalahan dalam penelitian ini adalah bagaimana pendistribusian zakat berbasis ekonomi yang dilakukan di Dompet Dhuafa Riau.Informan penelitian ini berjumlah tujuh orang.Data yang dikumpulkan melalui observasi, wawancara, dan dokumentasi serta dianalisis menggunakan metode deskriptif kualitatif. Penelitian ini menemukan bahwa Dompet Dhuafa Riau telah mendistribusikan dana zakat secra produktif melelui program yang ada pada bidang ekonomi. Adapun program-program itu diantaranya: Desa Berdaya, Institute Kemandirian, dan UMKM. Penelitian ini juga menemukan bahwa Dompet Dhuafa Riau menjadikan program desa berdaya sebagai program unggulan.Hal ini karena program tersebut berhasil memberikan kontribusi ekonomi kepada mustahik.Disamping itu, lembaga zakat lain seperti Baznas Provinsi Riau juga tertarik untuk berpartisipasi dalam program desa berdaya yang dikembangkan oleh Dompet Dhuafa Riau.Sehingga, Dompet Dhuafa Riau menjadikan program desa berdaya sebagai program unggulan dibidang ekonomi.
\end{abstract}

Kata kunci: Pendistribusian, Zakat, Ekonomi 


\section{Pendahuluan}

Indonesia memiliki beragam agama yang dianut oleh penduduknya, akan tetapi yang menjadi mayoritas adalah agama Islam. Dalam agama Islam terdapat 5 rukun Islam yang pada point ke empatnya adalah membayar zakat. Zakat merupakan kewajiban yang mesti dilaksanakan oleh umat muslim. Harta yang dimiliki oleh kita sebbagiannya adalah milik orang lain sehingga wajib dizakati untuk membersihkan baik itu diri dibersihkan melalui zakat fitrah dan membersihkan harta melalui zakat mall.

Riau merupakan salah satu Provinsi yang berada di pulau Sumatra dengan jumlah penduduk 6,4 juta jiwa berdasarkan hasil perekaman e-KTP pada tahun 2012. Dengan jumlah penduduk yang tidak sedikit, mayoritas penduduknya juga beragama Islam.Tidak hanya itu, Riau memiliki sumber daya alam yang berlimpah bahkan Riau termasuk salah satu dari tiga provinsi yang pertumbuhan ekonominya terbaik secara nasional.Hal ini tentunya berimbas pada tingginya potensi zakat di Provinsi Riau. Wakil Gubernur Riau, HR Mmabang Mit menyatakan bahwa potensi zakat di Provinsi Riau jika terealisasi seratus persen, bisa mencapai 6,4 triliun mengingat mayoritas penduduknya beragama Islam. ${ }^{1}$

Sejalan dengan meningkatnya jumlah penduduk di Provinsi Riau

${ }^{1}$ http://www.aktual.com/ekonomibisn is/104641,mayoritas-berpenduduk-muslimpotensi-zakat-di-riau-capai-triliunan, diakses pada hari Sabtu, 17 Februari 2018, Pukul 11.10. berdasarkan hasil perekaman e-KTP, melalui survey Badan Pusat Statistik (BPS) mengatakan bahwa jumlah penduduk Provinsi Riau yang berada dibawah garis kemiskinan hingga September 2017 menurun sebanyak 5.200 orang dibandingkan dengan tahun sebelumnya. ${ }^{2}$ Menurunya jumlah masyarakat miskin di Provinsi Riau tidak terlepas adanya keterlibatan antara instansi pemerintah, masyarakat, lembagalembaga non-profit seperti lembaga zakat, dan instansi lainnya.

Menurunnya angka kemiskinan dan besarnya potensi zakat yang ada di provinsi Riau, kini sejumlah lembaga zakat mulai bermunculan salah satunya adalah Dompet Dhuafa Riau.lembaga zakat Dompet Dhuafa Riau berdiri pada tahun 2013 awal yang berhikmad menghimpun dana zakat, infak, sedekah, dan wakaf (ZISWAF). Walaupun masih baru, Dompet Dhuafa Riau dalam penghimpunan dana zakat selalu meningkat di setiap tahunnya. Di tahun 2013 dana zakat yang terhimpun sebesar Rp. 74.154.000,00, tahun 2014 dana zakat terhimpun sebesar Rp. 119.303.496,00, tahun 2015 dana zakat yang terhimpun sebesar $\mathrm{Rp}$. 280.418.733,00, tahun 2016 sebesar Rp. 475.690.134,00, dan di tahun 2017 sebesar Rp. 537.202.856,59. ${ }^{3}$

Besarnya jumlah zakat yang terhimpun setiap tahunnya oleh Dompet Dhuafa Riau, dalam

${ }^{2} \mathrm{http}: / /$ versiriau.com/2018/01/02hasil -survey-bps-turun-5-200-orang-pendudukmiskin-di-riau-496-390-jiwa, diakses pada hari Rabu, 11 April 2018, Pukul 14.14.

3 Laporan Tahunan Annual Report Dompet Dhuafa Riau 2017 
membantu pemerintah untuk mengurangi kemiskinan di Riau, maka Dompet Dhuafa melakukan suatu pemberdayaan kepada masyarakat melalui program yang ada dibidang ekonomi melalui pendistribusian zakat yang produktif.Program ini bertujuan memperbaiki ekonomi masyarakat kelas bawah dan menjadikannya sebagai masyarakat mandiri.

Jenis Penelitian ini adalah penelitian deskriptif yang mengumpulkan informasi dan membuat deskriptif tentang suatu fenomena menurut apa adanya pada saat penelitian dilakukan. Sedangkan pendekatan yang digunakan dalam penelitian ini adalah pendekatan kualitatif, yaitu suatu proses pemecahan masalah yang diteliti dengan menggambarkan objek penelitian secara rinci. ${ }^{4}$

\section{Pengertian Pendistribusian}

Distribusi berasal dari bahasa inggris yaitu distribute yang berarti pembagian atau penyaluran, secara terminologi distribusi adalah penyaluran (pembagian) kepada orang banyak atau beberapa tempat. Pengertian lain mendefenisikan distribusi sebagai penyaluran barang keperluan sehari-hari oleh pemerintah kepada pegawai negri, penduduk, dan sebagainya. ${ }^{5}$

Menurut Philip Kotler distribusi adalah serangkaian organisasi yang saling tergantung yang terlibat dalam proses untuk

${ }^{4}$ Tohirin, Metode Penelitian Kualitatif, (Jakarta: Raja Grafindo Persada, 2012), hlm, 2.

${ }^{5}$ Poerwadaminta, Kamus Umum Indonesia, (Jakarta: Balai Pustaka, 1991), hlm, 269. menjadikan produk atau jasa yang siap untuk digunakan atau dikonsumsi. Dalam hal ini distribusi dapat diartikan sebagai kegiatan (membagikan, mengirimkan) kepada orang atau beberapa tempat. ${ }^{6}$

Secara garis besar, pendistribusian dapat diartikan sebagai kegiatan pemasaran yang berusaha memperlancar dan mempermudah penyampaian barang dan jasa dari produsen kepada konsumen, sehingga penggunaannya sesuai dengan yang diperlukan (jenis, jumlah, harga, dan saat dibutuhkan). Dengan kata lain distribusi merupakan aktifitas pemasaran yang mampu menciptakan nilai tambah produk melalui fungsi-fungsi pemasaran yang dapat merealisasikan kegunaan atau fasilitas bentuk, tempat dan kepemilikan dan memperlancar arus saluran pemasaran (marketing chanel flow) secara fisik dan non fisik. ${ }^{7}$

\section{Pengertian Zakat}

Secara etimologi kata zakat (alZakah) merupakan kata dasar dari zaka yang berarti suci, berkah tumbuh, dan terpuji, yang mana semua itu sangat popular dalam penerjemahan baik Al-Qur'an maupun Hadist. Sesuatu dikatakan zaka apabila ia tumbuh dan berkembang, dan seseorang disebut $z a k a$, jika orang tersebut baik dan terpuji.

Ditinjau dari segi terminologi fiqih seperti yang dikemukakan oleh pengarang Kifayah al-Akhyar,

\footnotetext{
${ }^{6}$ Fandy Tjiptono, Strategi Pemasaran, (Yogyakarta: Andi, 2001), hlm, 185.

${ }^{7}$ Fandy Tjiptono, Strategi Pemasaran, hlm, 185.
} 
$\begin{array}{lll}\text { Taqiyuddin } & \text { Abu } & \text { Baka } \\ \text { mendefinisikan, } & \text { zakat } & \text { adalah }\end{array}$ sejumlah harta tertentu yang diserahkan kepada orang-orang yang berhak dengan syarat tertentu. Adapun jumlah yang dikeluarkan dari kekayaan itu disebut zakat, karena yang dikeluarkan itu menambah banyak, membuat lebih berarti, dan melindungi kekayaan itu dari kebinasaan. ${ }^{8}$

Zakat menurut Abdullah adalah salah satu dari lima rukun Islam yang juga merupakan salah satu kewajiban yang mendasar dalam Islam. Tujuan utamanya adalah untuk mengembangkan pertumbuhan sosial ekonomi yang seimbang, dan untuk memurnikan jiwa dan kekayaan seseorang sehingga kekayaan mereka diberkati oleh Allah SWT.

Pada sisi lain, zakat merupakan ibadah maliyah (harta/kebendaan), yaitu pemberdayaan harta benda yang diberikan Allah kepada manusia yang digunakan untuk kepentingan bersama. Hal ini senada dengan aspek ekonomi, dimana zakat mengajak pada sebuah muara adanya kebersamaan untuk menikmati kesejahteraan sehingga muncul adanya pemerataan, kesamaan, dan kebersamaan. Zakat akan memberi makna yang begitu berarti bila didorong kepada upaya meningkatkan produktivitas penerimanya. Pemikiran ini sudah sejak lama digagas oleh ulama terkemuka Syeikh Arsyad al-Banjari, mereka (kaum dhuafa) bukan diberi sesuatu untuk jangka pendek, tetapi

${ }^{8}$ Sudirman, Zakat dalam Pusaran

Arus Modernitas,(Malang: UIN Malang Press, 2007), hlm. 14. mestinya diberikan sesuatu yang mampu menjamin kebutuhan dalam jangka panjang. ${ }^{9}$

1) Klasifikasi Zakat Bila ditinjau dari segi objek kewajiban zakat, maka zakat dapat diklasifikasikan kepada dua jenis yaitu;

A. Zakat Fitrah

Zakat fitrah terdiri dari dua suku kata, yaitu zakat dan fitrah.Kata zakat berarti ath-taharah (suci), assalah (baik), al-barakah (berkah), alnama (tumbuh dan berkembang). Kata fitrah merupakan isim masdar dari kata aftara-iftaran, yang artinya "jiwa atau diri". Dengan demikian, secara etimologi zakat fitrah adalah pensucian jiwa, perbaikan jiwa, keberkatan jiwa, dan menumbuh kembangkan potensi jiwa.

Secara terminologi, zakat fitrah adalah zakat yang diwajibkan bagi setiap individu (umat Islam), baik anak-anak maupun orang dewasa, laki-laki maupun perempuan, merdeka maupun hamba sahaya.Defenisi ini memberikan kesan bahwa zakat fitrah merupakan kewajiban individu yang tidak boleh ditinggalkan, baik oleh orang kaya maupun orang miskin. ${ }^{10}$

B. Zakat Mal

Secara terminology, menurut Moh Rifa'i zakat mal adalah zakat yang berhubungan dengan harta, yang dikeluarkan karena harta tersebut telah dimiliki penuh selama satu tahun (haul) dan memenuhi standar nisabnya (kadar minimum

${ }^{9}$ Noor Aflah, ed, Strategi Pengelolaan Zakat di Indonesia, (Jakarta: Forum Zakat, 2011), hlm 129.

${ }^{10}$ Tarmizi Tohor, Pemberdayaan Ekonomi Umat Melalui Zakat dan Wakaf, hlm, 10 . 
harta yang terkena zakat). Dalam terjamah Kifayat al-Ahyar harta yang wajib zakat ada 5 macam, ${ }^{11}$ yaitu; ternak, perhiasan (emas dan perak),tanaman (hasil tanaman), buah-buahan, dan perniagaan.

2) Syarat-Syarat Wajib Zakat

Zakat wajib dikeluarkan jika telah memenuhi syarat, adapun syarat wajib zakat adalah;Pertama, Islam.Kedua,merdeka.Ketiga, mencapai nishab.Keempat, sudah berlalu satu tahun (haul) kecuali terkait dengan hasil pertanian dan perkebunan.

Harta yang dizakatkan juga disyariatkan milik penuh dan berkuasa menggunakannya. Pada hakekatnya kepemilikan mutlak pada harta adalah Allah SWT, akan tetapi Allah memberikan hak kepemilikan harta kepada manusia secara terbatas. Hata milik penuh yang dimaksud adalah bahwa ia berkuasa memiliki dan memanfaatkannya secara penuh. ${ }^{12}$ Apabila syarat-syarat tersebut telah terpenuhi, maka tidak ada alasan untuk tidak mengeluarkan zakat, dan amil berkewajiban mengambil harta zakat tersebut dan menyalurkannya kepada mustahiq zakat melalui suatu pemberdayaan kepada masyarakat agar adanya perubahan kehidupan terutama dari sisi ekonomi untuk mencapai suatu kesejahteraan.

3) Golongan yang Berhak Menerima Zakat (Mustahiq) Orang yang berhak menerima zakat dalam UU No.38

${ }^{11}$ Moh Rifa'I, dkk, Terjamah Khulasah Kifayat Akhyar, (Semarang: Toha Putra, 1978), hlm, 123.

${ }^{12}$ Yusuf al-Qardawi, Fiqih al-Zakah, (Beirut: Muassasah al-Risalah, 1994), cet. Ke 22, hlm 143-181.
Tahun 198 tentang pengelolaan zakat dan menurut ketentuan Al-quran surah At-Taubah ayat 60, adalah:Pertama, fakir. Kedua, miskin. Ketiga, amil.Keempat, muallaf.Kelima, riqab.Keenam, gharim.Ketujuh, fii sabilillah.Kedelapan, ibnu sabil. ${ }^{13}$

\section{Pengertian Ekonomi}

Secara etimologi, kata "ekonomi" berasal dari bahasa Yunani yaitu $i$ (oikos),yang berarti "keluarga, rumah tangga" dan $\mu$ (nomos) yang berarti "peraturan, aturan, hukum".Ekonomi adalah ilmu yang mempelajari bagaimana manusia mencukupi kebutuhan hidupnya seperti produksi, distribusi, dan konsumsi terhadap barang dan jasa.Jadi pengertian ekonomi pada dasarnya adalah ilmu yang mengatur rumah tangga ${ }^{14}$.

Kemudian arti asli tersebut kini berkembang menjadi arti baru, sejalan dengan perkembangan ekonomi menjadi suatu ilmu. Sebagai ilmu, ekonomi berarti pengetahuan yang tersusun menurut cara yang runtut dalam rangka mengatur rumah tangga. Rumah tangga disini bukan dalam artian sempit, melainkan menunjuk pada kelompok sosial yang dapat dianggap sebagai suatu rumah tangga. Kelompok sosial ini dapat berwujud kota, perusahaan, bahkan negara. Berarti dalam pengertian luas, rumah tangga menunjuk pada kesatuan kelompok manusia yang

${ }^{13}$ K.N Sofyan Hasan, Pengantar Hukum Zakat dan Wakaf, (Surabaya: AlIkhlas, 1995), hlm, 43-46.

${ }^{14}$ Sukarno Wibowo dan Dedi Supriadi, Ekonomi Mikro Islam, (Bandung: Pustaka Setia, 2013), hlm, 13. 
hidup menurut norma dan tatanan aturan tertentu.

Ekonomi adalah bagian dari suatu tatanan Islam yang perspektif, Islam meletakkan ekonomi pada posisi tengah dan keseimbangan yang adil dalam bidang ekonomi keseimbangan diterapkan dalam segala segi antara modal dan usaha, antara produksi dan konsumsi, antara produsen dan konsumen, antara golongan-golongan dan masyarakat. ${ }^{15}$

Berdasarkan beberapa pendapat diatas dapat penulis simpulkan bahwa definisi ekonomi diatas mengarah kepada aktifitas manusia dalam memenuhi kebutuhan hidupnya atas apa yang diperlukan. Oleh karena itu ekonomi menurut penulis adalah aktifitas yang dilakukan secara berulang-ulang dalam memenuhi kebutuhan hidupnya.

\section{Pendistribusian Zakat}

Pendistribusian zakat adalah suatu aktifitas atau kegiatan untuk mengatur sesuai dengan fungsi manajemen dalam upaya menyalurkan dana zakat yang diterima dari muzakki kepada mustahik sehingga tercapainya tujuan organisasi secara efektif.

Pendistribusian zakat dari masa ke masa mengalami perubahan. Awalnya lebih banyak disalurkan untuk kegiata konsumtif tetapi belakangan ini dana zakat di manfaatkan secara produktif. Upaya seperti ini diharapkan dapat mengubah alur yang awalnya mustahik menjadi muzakki.

${ }^{15}$ Yusuf Qardhawi, Norma dan Etike Ekonomi Islam, (Jakarta: Gema Insani Pers, 2001), hlm, 33.
Zakat merupakan poros dan pusat keuangan Islam.Dalam bidang ekonomi zakat mencegah pemupukan kekayaan yang mengerikan pada seseorang, sebelum mendatangkan bahaya bagi pemiliknya maka sebagian diberikan kepada yang berhak.

Dalam istilah ekonomi Islam, zakat merupakan tindakan pemindahan kekayaan dari golongan kaya kepada golongan tidak punya. Transfer kekayaan berarti transfer sumber-sumber ekonomi. Tindakan ini tentu saja mengakibatkan perubahan tertentu yang bersifat ekonomis.Misalnya, seseorang yang berhak menerima zakat mendayagunakan untuk sesuatu yang produktif.

Salah satu syarat keberhasilan zakat dalam mencapai tujuan sosial kemanusiaan adalah dengan cara pendistribusian yang professional yang didasrkan kepada landasan yang sehat, sehingga zakat tidak salah sasaran. Dimana orang yang berhak menerimanya tidak mendapatkannya malah diberikan kepada yang tidak berhak atau berhak tapi memperoleh jumlah zakat yang tidak mencukupi atau diberikan kepada orang yang kondisi ekonominya lebih baik, sementara yang kondisi ekonominya kurang baik justru tidak mendapatkannya. Menurut Yusuf al-Qordhawi dalam bukunya yang berjudul "Manajemen Zakat Profesional", ada beberapa cara untuk mendistribusikan dana zakat secara professional yaitu:

1) Pola Pendistribusian Produktif

Pola pendistribusian produktif adalah pola penyaluran dana zakat kepada mustahik yang 
ada dipinjamkan oleh amil untuk kepentingan aktifitas suatu usaha/bisnis.

Pola penyaluran secara produktif (pemberdayaan) adalah penyaluran zakat dan lainnya disertai target merubah keadaan penerima lebih dikhususkan kepada mustahik/ golongan fakir, miskin dari kondisi kategori mustahik menjadi kategori muzakki.

2) Pendistribusian Secara Lokal

Para mustahik di masingmasing wilayah lebih diprioritaskan dari pada mustahik di wilayah lain, sebagaimana yang kita kenal dengan konsep otonomi daerah. Masingmasing daerah atau sejumlah daerah yang berdampingan lebih diprioritaskan untuk mendapatkan zakat orang-orang kaya setempat melalui lembaga amil zakat, unit pengelola zakat di daerah masyarakat itu tinggal. Disetiap negri Islam dapat mengikuti cara seperti ini, dimulai dari unit yang terkecil kemudian ke unit yang lebih besar. Pendistribusian dana zakat yang lebih dari lembaga pusat untuk membantu provinsi lain yang perolehan zakatnya kurang, atau kaum fakir dan orang-orang yang membutuhkannnya disbanding provinsi lain. Itulah petunjuk Islam dalam membelanjakan perolehan zakat dan itulah konsepnya yang arip dan bijaksana, yang sejalan dengan konsep manejemen dan politik keuangan yang paling maju/ modern di zaman sekarang ini.

3) Pendistribusian Yang Adil Terhadap Semua Golongan Adil terhadap semua golongan yang telah dijanjikan sebagai mustahik oleh Allah dan
Rasul-nya dan adil diantara semua individu dalam satu golongan mustahik.Yang dimaksud bukan menyamaratakan antara golongangolongan mustahik atau individu dalam setiap golongan itu, melainkan keadilan yang memperhatikan hak, besarnya kebutuhan, dan kemashalatan Islam yang tinggi.

Dalam hal ini penulis akan menjelaskan pendistribusian zakat berbasis ekonomi yang dilakukan oleh lembaga zakat yaitu Dompet Dhuafa Provinsi Riau.

Dompet Dhuafa Provinsi Riau dalam mendistribusikan zakat pada aspek ekonomi dilakukan melalui suatu program yang terbagi dalam tiga bentuk yaitu; desa berdaya, institute kemandirian, dan UMKM.

a) Desa Berdaya

Desa berdaya merupakan program yang ditujukan kepada para petani kecil yang memiliki potensi dalam bidang pertanian, tetapi berada dalam keterbatasan untuk menjalankan aktivitas pertanian yang dilakukan karena berbagai kendala seperti keterbatasan dana, lahan, peralatan, pupuk, bibit dan lain-lain.

Program pemberdayaan petani bawang merah yang berlokasi di Kelurahan Pebatuan, Kecamatan Tenayan Raya, Kota Pekanbaru.pemberdayaan petani bawang inilah yang menjadi cikal bakal untuk membangun desa berdaya, diamna petani-petani dhuafa dapat dibantu dengan bantuan muzaki agar mereka menjadi 
berdaya dan dapat meningkatakan perekonomian mereka.

b) Institute Kemandirian

\begin{tabular}{ccr}
\multicolumn{2}{c}{ Merupakan } & jejaring \\
program & Dompet & Dhuafa \\
Provinsi & Riau & dalam
\end{tabular}
pemberdayaan masyarakat melalui pelatihan soft skil, dan juga kebutuhan untuk meningkatkan kapasitas SDM dari kalangan usia produktif, dan dhuafa. Institut kemandirian Dompet Dhuafa Provinsi Riau dalam hal ini membantu mengatasi masalah pengangguran dan kemiskinan melalui berbagai pelatihan yaitu;
a. Pelatihan
Teknisi Handphone

b. Pelatihan Fashion/ Menjahit

c. Pelatihan design grafis (digital printing, sablon, dan advertising).

Adapun tahapan dari institut kemandirian dari Dompet Dhafa yang harus dipenuhi antara lain;

(1) Pendaftaran peserta

(2) Seleksi peserta

(3) Pendidikan pelatihan

(4) Magang

(5) Pendampingan

(6) Kemandirian alumni

\section{c) UMKM}

\begin{tabular}{lr}
\multicolumn{1}{c}{ Usaha mikro kecil } \\
menengah & merupakan \\
pendampingan yang diberikan \\
kepada UMKM & kecil yang \\
ingin & mengembangkan \\
usahanya & dengan \\
memperhatikan & nilai \\
pemberdayaan & masyarakat
\end{tabular}

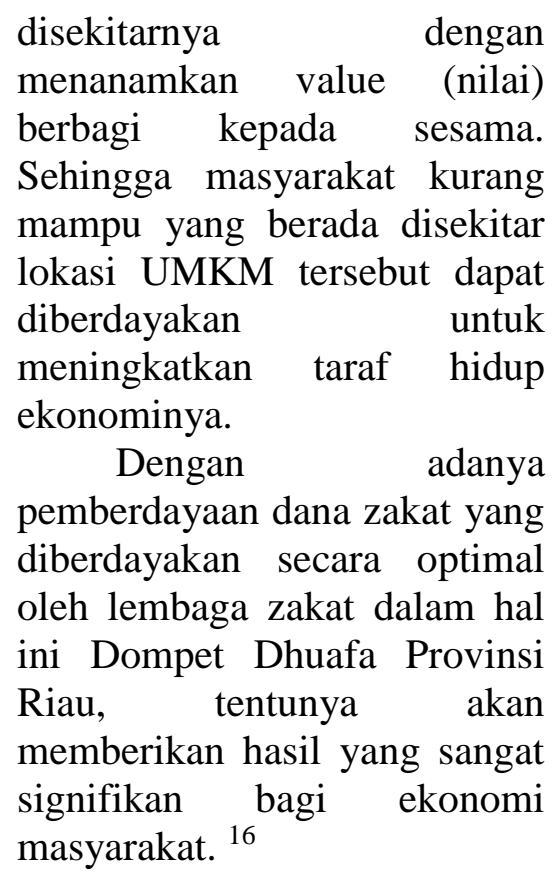

Desa Berdaya

Dompet Dhuafa Riau dalam mendistribusikan dana zakat kepada mustahiq dibidang ekonomi dibentuk beberapa program yang mengarah kepada pemberdayaan terhadap mustahiq yang bersifat produktif.

Zakat produktif adalah pemberian zakat yang dapat membuat para penerimanya menghasilkan sesuatu secara terus menerus, dengan harta zakat yang telah diterimanya. Dengan demikian zakat produktif adalah zakat dimana harta atau dana zakat yang diberikan kepada mustahik tidak dihabiskan akan tetapi dikembangkan dan digunakan untuk membantu usaha para mustahik, sehingga dengan usaha tersebut mustahik dapat terpenuhi kebutuhan hidup secara terus-menerus.

Pendistribusian zakat secara produktif dilembaga zakat

16 Data Dokumentasi AD/ART

Dompet dhuafa Riau 
kebanyakan mengarah pada suatu pemberdayaan. Pemberdayaan adalah serangkaian kegiatan untuk memperkuat kekuasaan atau keberdayaan kelompok yang lemah dalam masyarakat, dengan cara mendorong, memotivasi, dan membangkitkan kesadaran akan potensi yang dimiliki dan berupaya untuk mengembangkan potensi itu menjadi sebuah tindakan yang nyata. Seperti individu yang mengalami perekonomian lemah atau miskin. ${ }^{17}$

Pemberdayaan yang seperti ini merupakan suatu pemberdayaan yang bisa diarahkan kepada program yang dimiliki oleh Dompet Dhuafa Riau dibidang ekonomi.Dalam aplikasinya bentuk program yang ada di Dompet Dhuafa Riau salah satunya program desa berdaya.Program ini bertujuan supaya zakat yang disalurkan dapat berkembang dan mustahik tidak lagi menjadi miskin selamanya atau hidup tanpa ada pekerjaan yang tetap atau usaha dimiliki.

Desa berdaya adalah suatu program yang ditujukan kepada petani kecil pada bidang pertanian yang memiliki potensi, akan tetapi berada dalam kondisi yang serba terbatas baik itu dana, lahan, peralatan, pupuk, bibit dan lainnya. Program desa berdaya berlangsung sejak 2017 hingga sekarang dengan jumlah mustahik dulunya dua orang kini bertambah menajdi lima orang.

Menurut analisis penulis, bahwa Dompet Dhuafa Riau dalam

\footnotetext{
17 Edi Suharto, Membangun Masyarakat Memberdayakan Rakyat, Kajian Strategis Pembangunan Kesejahteraan Sosial dan Pekerjaan Sosial (Bandung:PT Refika Aditama, 2005), hlm 56.
}

mendistribusikan dana zakat secara produktif pada program desa berdaya sudah dilakukan dengan baik. Dengan adanya program desa berdaya ini bertujuan agar yang diberikan bantuan dana zakat suatu saat nanati mampu menjadi muzakki, dan menurut bapak Ali Bastoni selaku pimpinan Dompet Dhuafa Riau bahwa, pemberian bantuan ini mustahik diberikan pelatihan, pemberian kebutuhan peralatan usaha, pendampingan lapangan kepada mustahik, serta pengawasan. ${ }^{18}$ Artinya di sini, Dompet Dhuafa Riau dalam mendistribusikan dana zakat kepada mustahik tidak hanya memberikan dana zakat begitu saja, akan tetapi bagaimana dana zakat yang diberikan dapat memenuhi kebutuhan hidupnya sepanjang masa dengan memberdayakan skill yang dimiliki.

\section{Institute Kemandirian}

Kemandirian merupakan sikap tidak mau bergantung kepada orang lain. Namun, tuntutan sebagai manusia tetap harus berhubungan dengan orang lain. Kemandirian diawali dengan niat ingin melepaskan ketergantungan, kemudian diwujudkan dalam tekad yang kuat.Setelah itu, harus ada dorongan untuk mengubah tekad mencapai upaya yang nyata.

Institute kemandirian adalah sebuah program Dompet Dhuafa Riau yang me mberdayakan masyarakat melalui pelatihan soft skill, dan juga kebutuhan untuk meningkatkan kapasitas sumber daya

18 Ali Batoni, Pimpinan cabang Dompet Dhuafa Riau, wawancara tanggal, 12 Oktober 2018, pukul 13.24. 
manusia (SDM) dari kalangan usiaproduktif, dan dhuafa. Karena berbicara pengangguran dan kemiskinan, merupakan dua masalah bangsa yang tidak kunjung selesai.Berbagai program dan aksi terus digulirkan banyak pihak yang terlibat untuk mengatasinya.Akan tetapi semua belumlah cukup, diperlukan program dengan efektifitas yang tinggi untuk mengatasi dua masalah tersebut.

Dompet Dhuafa mencoba membuat rule model dengan mendirikan institute kemandirian. Adapun institute kemandrian yang ada di Dompet Dhaufa Riau yaitu adanya pelatihan teknisi handphone, pelatihan design grafis, dan pelatihan menjahit. Pelatihan teknisi handphone, dan pelatihan design grafis merupakan program dari Dompet Dhuafa pusat yang dilaksanakan di Dompet Dhuafa Riau, adapun segala teknisi dan lainnya Dompet Dhuafa pusat yang melaksanakan.Untuk itu penulis hanya menjelaskan pemberdayaan dibidang pelatihan menjahit yang dilaksanakan oleh Dompet Dhuafa Riau.

Menjahit merupakan suatu aktivitas usaha yang memiliki banyak peluang yang bisa memberikan masa depan yang cemerlang. Di zaman moderenisasi ini masyarakat sedang dibumingkan dengan berbagai model fashion mulai dari model celana, rok, baju, jilbab dan lainnya.Keadaan ini memberikan peluang usaha untuk membuka jasa menjahit agar terpenuhinya kebutuhan konsumen. Wawancara dengan Tya selaku CRM di Dompet Dhuafa Riau mengatakan bahwa, dengan adanya pelatihan menjahit ini, mustahik dapat meningkatkan taraf ekonominya serta pengangguran dan kemiskinan dapat di minimalisir. ${ }^{19}$

Dana zakat yang didistribusikan oleh Dompet Dhuafa Riau diberikan kepada mustahik untuk mengembangkan sebuah usaha produktif, dimana dalam pelaksanaanya tetap dibina dan dibimbing. Pendistribusian zakat yang bersifat produktif ini sangat tepat untuk mengurangi kemiskinan yang ada di wilayah Riau. kita berharap dengan adanya zakat produktif ini dapat melahirkan muzakki-muzakki baru. Dengan kata lain, mereka yang tahun ini merupakan penerima zakat, dengan adanya zakat produktif satu, dua, atau tiga tahun kedepan dapat menjadi muzakki.

Menurut analisis penulis, Dompet Dhuafa Riau dalam mendistribusikan dana zakat dilakukan secara keratif, dengan kata lain tidak memberikan dana zakat kepada mustahik secara konsumtif melainkan didistribusikan secara produktif melalui pelatihan menjahit dengan memberdayakan kemampuan dari mustahik itu sendiri, agar nantinya mustahik menjadi lebih mandiri.

\section{UMKM}

Menurut UUD 1945 yang kemudian dikuatkan melalui TAP MPR No.XVI/MPR-RI/1998 tentang politik ekonomi dalam rangka demokrasi ekonomi, usaha mikro, kecil, dan menengah perlu diberdayakan sebagai bagian integral ekonomi rakyat yang mempunyai

19 Tya Mariza, bagian CRM Dompet Dhuafa Riau, wawancara tanggal, 19 Oktober 2018, pukul 15.30. 
kedudukan, peran, dan potensi strategis untuk mewujudkan struktur perekonomian nasional yang makin seimbang, berkembang, dan berkeadilan. Selanjutnya dibuatlah pengertian UMKM melalui UU No.9 Tahun 1999 dan karena keadaan perkembangan yang semakian dinamis dirubah ke UU No.20 pasal 1 Tahun 2008 tentang usaha mikro, kecil, dan menengah maka pengertian UMKM adalah sebagai berikut:Pertama, Usaha mikro adalah usaha produktif milik orang perorangan dan / atau badan usaha perorangan yang memenuhi criteria usaha mikro sebagaimana diatur dalam Undang-undang ini.Kedua, Usaha kecil adalah usaha ekonomi produktif yang berdiri sendiri, yang dilakukan oleh orang perorangan atau badan usaha yang bukan merupakan anak perusahaan atau bukan cabang perusahaan yang memiliki, dikuasai, atau menjadi bagian baik langsung maupun tidak langsung dari usaha menengah atau usaha besar yang memenuhi kriteria usaha kecil sebagaimana dimaksud dalam Undang-undang ini.Ketiga, Usaha menengah adalah usaha ekonomi produktif yang berdiri sendiri, yang dilakukan oleh orang perorangan atau badan usaha yang bukan merupakan anak perusahaan atau cabang perusahaan yang dimiliki, dikuasai, atau menjadi bagian baik langsung maupun tidak langsung dengan usaha kecil atau usaha besar dengan jumlah kekayaan bersih atau hasil penjualan tahunan sebagaimana diatur Undang-undang ini. $^{20}$

\footnotetext{
${ }^{20}$ Yuli Rahmini Suci, "Perkembangan UMKM (Usaha Mikro Kecil dan Menengah) di Indonesia", Jurnal Ilmiah Cano
}

Sektor UMKM sering disebut sebagai kegiatan ekonomi berbasis kerakyatan umumnya barang-barang yang dihasilkan oleh pelaku UMKM adalah berupa kebutuhan sehari-hari yang dibutuhkan oleh hampir semua lapisan masyarakat. UMKM menjadi tulang punggung sistem ekonomi kerakyatan untuk mengurangi permasalahan kemiskinan dan pengembangannya mampu memperluas basis ekonomi serta dapat memberikan kontribusi yang signifikan dalam meningkatkan perekonomian daerah dan ketahanan ekonomi nasional. ${ }^{21}$

UMKM merupakan salah satu langkah yang mesti dilakukan dan menjadi perhatian yang serius, dengan adanya UMKM masyarakat ekonomi kelas bawah bisa terbantu dan tidak hanya itu UMKM sebagai salah satu cara memperkecil tingkat pengangguran dan kemiskinan, yang tujuannya adalah memberikan kesejahteraan.

Program UMKM yang dilakukan oleh Dompet Dhuafa Riau adalah herbal ice dengan memberdayakan masyarakat miskin atau dhuafa melalui pendistribusian zakat produktif.Herbal ice diberdayakan sejak Januari 2017 hingga sekarang serta mengalami perkembangan yang cukup baik.

Dalam pendistribusian zakat kepada mustahik, Dompet Dhuafa Riau terlebih dahulu melakukan

Ekonomos, Vol. 6 ,No. 1 (Januari 2017), hlm 54.

21 Rizki Tri Prasetio dkk, "Upaya Peningkatan Produktivitas UMKM Melalui Implementasi ICT pada Look At Hijab Bandung", Jurnal Pengabdian kapada Masyarakat Vol. 1 ,No. 1 (Februari 2018), hlm 105. 
observasi atau peninjauan lapangan tentang keadaan mustahik yang sebenarnya dan apakah sesuai usaha herbal ice ini diberdayakan kepada mustahik tersebut.

Dompet Dhuafa Riau sendiri juga memvariasi dalam pendistribusian zakat kepada mustahik, pada usaha herbal ice mustahik diberikan sejumlah uang yang kemudian hanya boleh dipergunakan untuk pembelian alatalat untuk pembuatan herbal ice yang dibuktikan melalui kwitansi serta diserahkan kepada pihak Dompet Dhuafa Riau. ${ }^{22}$ Pendistribusian zakat ini sedikit berbeda dari program desa berdaya dan pelatihan menjahit, dimana kedua program ini Dompet Dhuafa memberikan sejumlah uang untuk modal usaha dan juga pemberian peralatan sesuai dengan yang dibutuhkan. Akan tetapi arah dan bentuknya tetaplah sama yaitu pendistribusian dana zakat secara produktif, dengan memanfaatkan skill dan kemauan mustahik untuk meningkatkan perekonomiannya.

Menurut analisis penulis, Dompet Dhuafa Riau telah melakukan pemberdayaan kepada mustahik melalui zakat produktif. Sejauh ini, Dompet Dhuafa Riau tidak mau hanya memberikan dana zakat kepada mustahik begitu saja, karena pendistribusian zakat secara konsumtif tidak menjadikan mustahik mandiri, serta pemberian dana zakat secara berulang dengan orang yang sama bukanlah langkah untuk mengatasi kemiskianan untuk itulah Dompet Dhuafa Riau melakukan pendistribusian zakat

${ }^{22}$ Firman Nuryanto, Bagian program Dompet Dhuafa Riau, wawancara tanggal, 16 Oktober 2018, pukul 13.14. secara produktif mellaui program yang bisa memberdayakan mustahik.

\section{Kesimpulan}

Berdasarkan Pembahasan tentang Pendistribusian Zakat Berbasis Ekonomi pada Dompet Dhaufa Provinsi Riau, dapat disimpulkan bahwa Dompet Dhuafa Riau telah mendistribusikan dana zakat secara produktif melalui program yang mengarah pada pemberdayan terhadap mustahik. Adapun pemberdayaan dilakukan melalui program yang ada di Dompet Dhuafa Riau yaitu: Desa Berdaya, Institut Kemandirian, UMKM.

Adanya program yang mengarah pada pemberdayaan melalui pendistribusian zakat secara produktif, sejauh ini mampu meningkatkan perekonomian mustahik menjadi lebih baik dibandingkan sebelumnya serta menjadikan mustahik menjadi lebih mandiri.

Penelitian ini juga menemukan bahwa Dompet Dhuafa Riau menjadikan program desa berdaya sebagai program unggulan.Hal ini karena program tersebut berhasil memberikan kontribusi ekonomi kepada mustahiq.

Disamping itu, lembaga zakat lain seperti Baznas Provinsi Riau juga tertarik untuk berpartisipasi dalam program desa berdaya yang dikembangkan oleh Dompet Dhuafa Riau.Sehingga, Dompet Dhuafa Riau menjadikan program desa berdaya sebagai program unggulan dibidang ekonomi. 


\section{Daftar Pustaka}

Aflah, Noor, ed. (2011).Strategi Pengelolaan Zakat di Indonesia, Jakarta: Forum Zakat.

Al-Qardawi, Yusuf. (1994).Fiqih alZakah, Beirut: Muassasah alRisalah.

Hasan,K.N

Sofyan. (1995).Pengantar Hukum Zakat dan Wakaf, Surabaya: Al-Ikhlas.

Poerwadaminta. (1991). Kamus Umum Indonesia, Jakarta: Balai Pustaka.

Rifa'i, Moh, dkk. (1978). Terjamah Khulasah Kifayat Akhyar, Semarang: Toha Putra.

Qardhawi, Yusuf. (2001). Norma dan Etike Ekonomi Islam, Jakarta: Gema Insani Pers.

Sudirman. (2007).Zakat dalam Pusaran Arus Modernitas, Malang: UIN Malang Press.

Suharto, Edi. (2005).Membangun Masyarakat Memberdayakan Rakyat, Kajian Strategis Pembangunan Kesejahteraan Sosial dan Pekerjaan Sosial Bandung:PT Refika Aditama.

Supriadi, Dedi, dan Sukarno Wibowo. (2013).Ekonomi Mikro Islam, Bandung: Pustaka Setia, 2013..

Tjiptono, Fandy. (2001).Strategi Pemasaran, Yogyakarta: Andi.
Tohirin. (2012).Metode Penelitian Kualitatif, Jakarta: Raja Grafindo Persada.

Tohor, Tarmizi. (2014)Pemberdayaan Ekonomi Umat Melalui Zakat dan Wakaf, Pekanbaru: Kantor Wilayah Kementerian Agama.

\section{Daftar Journal :}

Prasetio, Rizki Tri, dkk. (2018) "Upaya Peningkatan Produktivitas UMKM Melalui Implementasi ICT pada Look At Hijab Bandung", Jurnal Pengabdian kapada Masyarakat Vol. 1 ,No. 1.

Suci, Yuli Rahmini,(2017) "Perkembangan UMKM (Usaha Mikro Kecil dan Menengah) di Indonesia", Jurnal Ilmiah Cano Ekonomos, Vol. 6 ,No.

\section{Daftar Akses :}

http://www.aktual.com/ekonomibisni s/104641,mayoritasberpenduduk-muslimpotensi-zakat-di-riau-capaitriliunan, diakses pada hari Sabtu, 17 Februari 2018, Pukul 11.10.

http://versiriau.com/2018/01/02hasilsurvey-bps-turun-5-200orang-penduduk-miskin-diriau-496-390-jiwa, diakses pada hari Rabu, 11 April 2018, Pukul 14.14. 